\title{
Review
}

\section{GPCRs and cancer}

\author{
Rosamaria LAPPANO, Marcello MAGGIOLINI* \\ Department of Pharmaco-Biology, University of Calabria, Rende (CS), Italy
}

G-protein-coupled receptors (GPCRs), which represent the largest gene family in the human genome, play a crucial role in multiple physiological functions as well as in tumor growth and metastasis. For instance, various molecules like hormones, lipids, peptides and neurotransmitters exert their biological effects by binding to these seven-transmembrane receptors coupled to heterotrimeric G-proteins, which are highly specialized transducers able to modulate diverse signaling pathways. Furthermore, numerous responses mediated by GPCRs are not dependent on a single biochemical route, but result from the integration of an intricate network of transduction cascades involved in many physiological activities and tumor development. This review highlights the emerging information on the various responses mediated by a selected choice of GPCRs and the molecular mechanisms by which these receptors exert a primary action in cancer progression. These findings provide a broad overview on the biological activity elicited by GPCRs in tumor cells and contribute to the identification of novel pharmacological approaches for cancer patients.

Keywords: cancer; G-protein-coupled receptors; heterotrimeric G-proteins; hormones; lipids; peptides; signal transduction

Acta Pharmacologica Sinica (2012) 33: 351-362; doi: 10.1038/aps.2011.183; published online 23 Jan 2012

\section{Introduction}

The seven-transmembrane $G$ protein-coupled receptors (GPCRs), which belong to the largest superfamily of signal transduction proteins, regulate multiple biological functions coupling to a heterotrimeric G-protein associated with the inner surface of the plasma membrane $e^{[1]}$. The heterotrimer that is composed of the Ga, G $\beta$, and $G \gamma$ subunits, binds to the guanine nucleotide GDP in its basal state. Upon activation by ligand binding, GDP is released and replaced by GTP, which leads to subunit dissociation into a $\beta \gamma$ dimer and the GTPbound a monomer ${ }^{[2]}$ (Figure 1). On the basis of the sequence identity, the Ga subunit has been classified into four families: $\mathrm{Ga}_{\mathrm{s}}, \mathrm{Ga}_{\mathrm{i}}, \mathrm{Ga}_{\mathrm{q}}$, and $\mathrm{Ga}_{12}$. Each Ga family can relay the GPCR signal stimulating different downstream effectors ${ }^{[2]}$. Some GPCRs, such as the lysophosphatidic acid (LPA) receptors, can couple to more than one $G$ protein triggering consequently diverse signaling cascades, whereas other GPCRs like sphingosine-1-phosphate (S1P) receptor 1 (S1P1) couple exclusively to one $\mathrm{G}$ protein ${ }^{[3,4]}$.

An increasing number of studies links aberrant GPCR expression and activation to numerous types of human malignancies $^{[5,6]}$ (Figure 1). For instance, several GPCRs are overexpressed in different tumors ${ }^{[6]}$ and GPCR variants can lead to increased cancer risk. In this regard, it should be mentio-

\footnotetext{
* To whom correspondence should be addressed.

E-mail marcellomaggiolini@yahoo.it

Received 2011-10-13 Accepted 2011-12-01
}

ned that in genetic association studies melanocortin-1 receptor (MC1R) polymorphisms were associated with an enhanced threat of skin cancer ${ }^{[7]}$. In addition, an aberrant activation of GPCRs by high levels of ligands like LPA, S1P and chemokines was involved in cell transformation, proliferation, angiogenesis, metastasis and drug resistance ${ }^{[6]}$. Conversely, some members of GPCRs, such as the orexin receptor OX1R, were shown to mediate a pro-apoptotic action in various cancer cells $^{[8]}$.

Cross-talk among different receptors including GPCRs triggers relevant biological functions in normal and neoplastic cells $^{[9]}$. In this context, it has been reported that many GPCRs activate numerous signaling pathways interacting with other plasma membrane receptors ${ }^{[9]}$ (Figure 1). For example, the cross-talk between acetylcholine muscarinic receptors (mAChRs) and epidermal growth factor (EGFR) as well as platelet-derived growth factor (PDGFR) receptors leads to the activation of mitogenic pathways which mediate cell proliferation, differentiation and survival ${ }^{[10]}$. In addition, several GPCR ligands like bradikinin (BK), LPA, Gastrin-releasing peptide $(\mathrm{GrP})$ and bombesin (BN) transactivate EGFR, then inducing stimulatory effects in different types of tumors ${ }^{[6]}$.

Currently, many agents targeting GPCRs, such as gonadotropin-releasing factor and somatostatin receptors, are used for cancer treatment on the basis of valuable experimental data and clinical benefits ${ }^{[11,12]}$. Moreover, various inhibitors of GPCRs are currently under evaluation in clinical trials as anticancer agents (http://www.clinicaltrials.gov/). This 


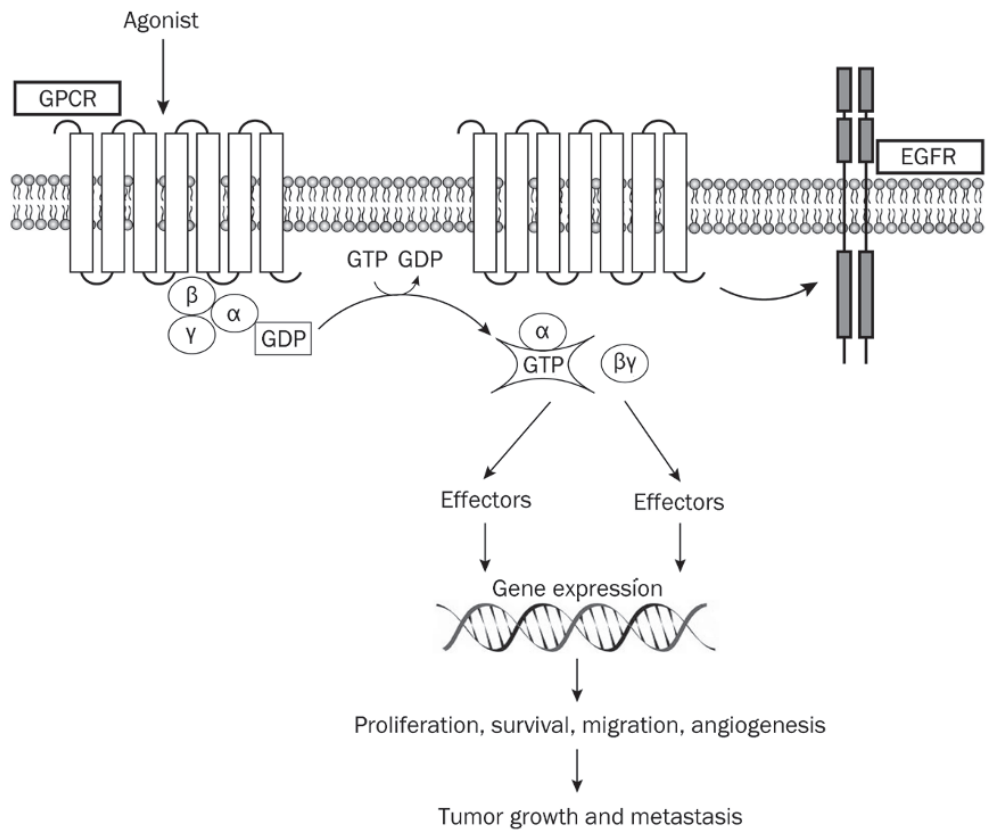

Figure 1. Agonist binding to GPCRs promotes the dissociation of GDP bound to the G $\alpha$ subunit and its replacement with GTP leading to the activation of the heterotrimeric $G$ proteins and the subunit dissociation into a $\beta Y$ dimer and the GTP-bound $\alpha$ monomer. Both subunits activate multiple downstream effectors which induce gene transcription and relevant biological responses. A cross-talk between several GPCRs and other membrane receptors as Epidermal Growth Factor Receptor (EGFR) contributes to the growth stimulation and invasion of cancer cells. review recapitulates our current understanding regarding the mechanisms through which various GPCRs may contribute to tumor progression. On these bases, GPCRs may be considered as promising targets in novel pharmacological approaches for cancer patients.

\section{GPCRs activated by bio-active lipids}

GPCRs activated by the bio-active lipids LPA and S1P have been implicated in aberrant signaling in a wide range of tumors. LPA1, LPA2 and LPA3 represent the most widely expressed and well-characterized receptors for LPA and its analogues $^{[3]}$. Upon binding to these receptors, LPA triggers a variety of signaling pathways engaging the heterotrimeric $G$ proteins and their downstream effectors ${ }^{[3]}$. As a consequence, the transcriptional activation of multiple cancer-associated genes leads to cell survival and proliferation, migration, chemotaxis, vascular remodeling and angiogenesis ${ }^{[13]}$. Aberrant expressions and mutations of LPA receptors have been found in several types of tumors, suggesting their involvement in the growth advantage of cancer cells ${ }^{[3,14,15]}$. For instance, LPA1 was inversely correlated in breast cancer tissues with the Nm23 metastases regulator ${ }^{[16]}$ and contributed to bone metastasis in breast cancer xenografts ${ }^{[17]}$. Furthermore, LPA induced migration in breast cancer cells by activating LPA1, which promoted the phosphorylation of nonmuscle myosin II (NM II) light chain through the activation of ROCK and RhoA activity $^{[18]}$. In addition, the expression of LPA1, LPA2, and LPA3 in mammary epithelium of transgenic mice induced a high frequency of late-onset, estrogen receptor (ER)-positive, invasive and metastatic mammary cancer ${ }^{[19]}$. LPA stimulated also tumorigenesis and metastasis in ovarian malignancy ${ }^{[20]}$. For instance, LPA exerted a growth factor-similar action and prevented apoptosis in ovarian cancer cells through redox-dependent activation of ERK, Akt and NF-kB-dependent signaling ${ }^{[21]}$.
Recently, the LPA/LPA1-induced Rac activation as well as the integrity of SOS1/EPS8/ABI1 tri-complex were required for ovarian cancer metastasis ${ }^{[22]}$. Closely resembling the LPAeffects in human ovarian cancer cells, LPA induced metastasis of epithelial ovarian cancer in immuno-competent mice ${ }^{[23]}$. As other GPCR ligands, LPA promoted stimulatory effects in different types of tumors by transactivating EGFR and triggering a functional cross-talk between its cognate receptors and EGFR-mediated signaling ${ }^{[6]}$. In this regard, it should be mentioned that EGFR activity was required for the activation of Gi-dependent cellular responses induced by LPA in ovarian cancer cells ${ }^{[24]}$. Moreover, a cross-talk between LPA receptors and EGFR occurred in ovarian cancer cells as demonstrated by the increase of LPA production following ligand-dependent EGFR transactivation ${ }^{[25]}$. In addition to breast and ovarian malignancies, LPA was involved in other types of tumors. In a murine xenograft model of lung adenocarcinoma, mesenchymal stem cells were recently shown to stimulate angiogenesis through a LPA1-dependent mechanism ${ }^{[26]}$. Likewise, an engineered three-dimensional tumor xenograft model of nonsmall cell lung cancer (NSCLC) in nude mice regressed and lost vascularity in response to BrP-LPA, which acts as a LPA receptor antagonist and autotaxin inhibitor ${ }^{[27]}$.

The bio-active lipid S1P has been involved in various aspects of tumor development, including cell proliferation, motility and invasiveness, apoptosis, differentiation, angiogenesis and inflammation ${ }^{[28]}$. However, S1P can mediate both proliferative $^{[29]}$ and antiproliferative ${ }^{[30]}$ effects in neoplastic cells. These opposite responses to S1P were attributed to the different activities exerted by its five receptors, which are coupled to distinct members of the $G$ protein family and display a specific tissue expression pattern ${ }^{[28]}$. In particular, S1P1 mediated promigratory effects ${ }^{[31]}$, whereas S1P2 inhibited cell migration ${ }^{[32]}$. An increased S1P1 expression, which was recently induced by 
the activator of transcription-3 (STAT3), up-regulated IL-6 and accelerated tumor growth and metastasis ${ }^{[33]}$. In glioblastoma and in Wilms tumor cells S1P-dependent S1P1 signaling induced cell migration and invasion ${ }^{[34,35]}$, whereas in glioblastoma and melanoma cells S1P-dependent S1P2 pathway negatively directed migration and invasion ${ }^{[32,36]}$. Paralleling the aforementioned observations, S1P1 and S1P2 exerted opposite effects on tumor angiogenesis. For instance, S1P1 stimulated angiogenesis $^{[37]}$ and accordingly the administration of monoclonal anti-S1P antibody prevented tumor growth by inhibiting angiogenesis and motility, survival and proliferation ${ }^{[38]}$. In addition, S1P1 was shown to be up-regulated in vessels at sites of tumor implantation, whereas S1P1 silencing resulted in the inhibition of tumor growth ${ }^{[39]}$. In contrast to the Gi-dependent S1P1 stimulation of tumor angiogenesis, S1P2 mediated inhibitory effects on tumor angiogenesis through G12/Rho signaling ${ }^{[40]}$. Together, these data suggest that the different action elicited by S1P1 and S1P2 may serve for novel pharmacological strategies based on therapeutics able to inhibit S1P1 and to activate S1P2 simultaneously.

\section{GPCRs activated by peptides}

The endothelin receptors $\left(\mathrm{ET}_{\mathrm{A}} \mathrm{R}\right.$ and $\left.\mathrm{ET}_{\mathrm{B}} \mathrm{R}\right)$ have been broadly involved in the regulation of mitogenesis, cell survival, angiogenesis, lymphangiogenesis, invasion and metastatic dissemination as well as epithelial-to-mesenchymal transition (EMT) in diverse types of malignancies ${ }^{[41]}$. Accordingly, high plasma endothelin-1 (ET-1) levels correlated with the tumor stage in cancer patients, suggesting that ET-1 can also serve as a prognostic marker ${ }^{[41,42]}$. Emerging data demonstrate that interfering with the ET receptors-dependent pathways may provide a significant chance for the development of novel anticancer strategies, in particular using $\mathrm{ET}_{\mathrm{A}} \mathrm{R}$ antagonists in combination with EGFR inhibitors as well as cytotoxic drugs ${ }^{[33]}$. Nevertheless, antagonists of ET receptors, like atrasentan and zibotentan (ZD4054), used alone have also gained considerable interest in human clinical trials on the basis of their potential anticancer activity ${ }^{[43]}$. For instance, the $\mathrm{ET}_{\mathrm{A}} \mathrm{R}$ blockade with the specific $\mathrm{ET}_{\mathrm{A}} \mathrm{R}$ antagonist zibotentan restored drug sensitivity to cytotoxic-induced apoptosis and inhibited ovarian cancer cell invasion ${ }^{[44]}$.

The four receptors for the Gastrin-releasing peptide (GrP) were shown to be able to transactivate EGFR in lung, head and neck squamous tumor cells ${ }^{[45,46]}$. In addition, ligand-stimulation of GrP receptors contributed to the growth of several malignancies through the activation of diverse phospholipases and protein kinases ${ }^{[47]}$. As GrP receptors were found overexpressed in a wide variety of tumors, their inhibition has been suggested as a promising objective in some malignancies ${ }^{[47]}$. Hence, the use of antagonists of GrP receptors represents a potential approach to inhibit the GrP-dependent effects on tumor growth. In this regard, it was demonstrated that the anti-tumor activity of GrP antagonists involves different mechanisms as the reduction of EGFR and Her2 levels, the alteration of MAPK, PKC, pAkt, and COX-2 signaling, the attenuation of $\mathrm{c}$-fos and c-jun expression, the modulation of wild-type and mutated forms of p53 along with an alteration of Bcl-2/BAX ratio, the inhibition of vascular endothelial growth factor (VEGF) ${ }^{[47]}$. Radiolabeled GrP analogues represent another chance in targeting GrP receptors, thus they are currently considered promising radiopharmaceuticals for detection and treatment of different types of tumors ${ }^{[48,49]}$.

Protease-activated receptors (PARs) are a unique class of GPCRs that are activated by proteolytic cleavage of their extracellular domains ${ }^{[50]}$. PAR-1 exerted a functional role in the growth, migration and metastasis in various tumors ${ }^{[51-53]}$. For instance, its proteolytic activation by thrombin caused persistent activation of EGFR/ERK signaling, promoting thereafter breast carcinoma cell invasion ${ }^{[54]}$. Moreover, PAR-1 negatively regulated the expression of the Maspin tumor-suppressor gene contributing to the metastatic phenotype of melanoma ${ }^{[55]}$. It has been recently reported that metalloprotease-1 (MMP1) may function as a protease agonist of PAR-1 which then stimulates migration, invasion and angiogenesis in breast and ovarian malignancies ${ }^{[56,57]}$.

Activation of the canonical Wnt pathway occurs through the seven-transmembrane Frizzled (Fzd) family receptors and the co-receptors lipoprotein receptor-related protein (LRP) in order to initiate the $\beta$-catenin signaling cascade ${ }^{[58]}$. The activated $\beta$-catenin translocates from the cytoplasm to the nucleus inducing the transcription of Wnt-responsive genes ${ }^{[58]}$. Numerous studies have shown that the dysregulation of the canonical Wnt pathway may lead to cancer development and progression $^{[58]}$. In this regard, mutations of $\beta$-catenin, axin and other components of the Wnt pathway ${ }^{[59]}$ as well as the activation of tissue-specific Wnt target genes ${ }^{[60,61]}$ were found in a variety of human tumors. In addition, the non-canonical Wnt pathways that act independently of $\beta$-catenin promote the invasiveness and progression of tumors ${ }^{[62]}$. Several Fzd receptors are highly expressed in a variety of malignancies and involved in cancer cell growth, survival and invasion through both canonical and non-canonical Wnt pathways ${ }^{[6]}$. For instance, the pharmacological inhibition of Fzd7, which is frequently overexpressed in hepatocellular carcinoma (HCC), displayed anti-tumor properties by involving $\beta$-catenin and PKC signals $^{[63]}$. Fzd7 was also crucial through the canonical Wnt pathway for cell proliferation and invasiveness in triple negative breast cancer cells as well as for tumor formation in xenograft models ${ }^{[64]}$. Moreover, the increased expression of Fzd4 through the up-regulation of $\beta$-catenin dependent Wnt signaling promoted in invasive glioma cells the acquisition of glioma stem cell-like properties and resistance to apoptosis ${ }^{[65]}$. Next, a cross-talk between Wnt pathways and EGFR signaling occurred in multiple stages of cancer development ${ }^{[59]}$.

The Hedgehog (Hh) signaling, which plays a key role in embryonic development, has been involved in the development of multiple malignancies ${ }^{[66]}$. Hh ligands are secreted from different tissues at various stages of development and generate intracellular signaling by binding to and inactivating the Hh receptor Patched-1 (Ptch1), which relieves its catalytic inhibition of the GPCR-like signal transducer Smoothened (Smo). The activation of Smo triggers downstream events 
that culminate in the stimulation of the glioma-associated oncogene homologue (GLI) transcription factors, the up-regulation of target genes like cyclins, Bcl-2 and SNAIL and the production of VEGF and angiopoietins ${ }^{[6]]}$. Consequently, $\mathrm{Hh}$ signaling contributes to cancer cell proliferation and survival, angiogenesis and metastasis ${ }^{[6]}$. In addition, mutations in components of the Hh pathway, such as Smo and Ptch1, lead to a constitutively activated Hh signaling in the absence of ligands in diverse cancer types, including basal cell carcinoma, medulloblastoma and non-small cell lung carcinoma ${ }^{[66-68]}$. The overexpression of Hh ligands have been also identified in several tumors as a stimulating factor acting in an autocrine manner to induce cell proliferation and survival ${ }^{[69]}$. Likewise, $\mathrm{Hh}$ ligands produced by stromal cells can promote tumor growth and survival in a paracrine manner ${ }^{[69]}$. Conversely, tumor cells can produce Hh ligands which activate transduction pathways in stromal cells ${ }^{[6]]}$. Several small molecule antagonists for Smo have been developed with a promising preclinical efficacy in multiple tumors. For instance, the Smo inhibitor CUR61414 inhibited in mice skin the Hh signaling, blocked the induction of hair follicle anagen and shrank in basal cell carcinomas (BCCs), although in a phase I clinical study it did not show any activity in human superficial or nodular $\mathrm{BCCs}^{[70]}$. Several other Smo antagonists, such as IPI-926, BMS-833923 and GDC-0449, are currently under evaluation in clinical trials as anticancer agents (http://www.clinicaltrials.gov/). In particular, GDC-0449 produced promising antitumor responses in a phase I study in patients with advanced BCCs as well as in a 26-year-old man with metastatic medulloblastoma which was unmanageable by conventional therapies ${ }^{[71]}$. However, the response of this patient to GDC-0449 treatment was only transient due to a mutation of Smo ${ }^{[7]}$. Recently, a number of Hh pathway antagonists targeting Smo mutants ${ }^{[72]}$ as well as inhibitors able to block both wild-type and Smo mutants have been identified ${ }^{[73]}$. In addition to Smo antagonists, other inhibitors were used to block Hh signaling like the small molecule inhibitor of GLI1 and GLI2 transcription factors, GANT61, which induced colon carcinoma cell death in a higher extent respect to the conventional Smo inhibitor cyclopamin ${ }^{[74]}$. The treatment with GANT61 reduced also the expression of the target gene Patched and decreased the viability of chronic lymphocytic leukemia cells ${ }^{[75]}$. Recently, the systemic antifungal itraconazole which failed to bind to Smo at the same binding site of cyclopamine, showed a potent antagonism for the Hh signaling pathway associated with anti-tumor activity in a mouse medulloblastoma allograft model ${ }^{[76]}$.

\section{GPCRs activated by chemokines}

Besides their functions in the immune system as mediators of leukocyte migration, chemokines and the cognate receptors play a critical role in tumor initiation and progression, including angiogenesis, attraction of leukocytes and induction of cell migration and homing in metastatic sites ${ }^{[77]}$. The first described angiogenic chemokine, CXCL8/IL-8, which binds to CXCR1 and CXCR2 ${ }^{[78]}$, is secreted by a variety of normal and tumor cells exposed to pro-inflammatory cytokines like
IL-1 and TNF-a ${ }^{[79]}$. CXCR2 was associated to multiple signaling pathways involved in tumorigenesis, angiogenesis, proliferation and metastasis in several malignancies, including melanoma ${ }^{[80]}$, lung ${ }^{[81]}$, pancreatic ${ }^{[79,82]}$, gastric ${ }^{[83]}$, and ovarian ${ }^{[57]}$ tumors. For instance, the overexpression of CXCR2 induced an aggressive phenotype of melanoma cells consisting with an enhanced proliferation, migration and tumor growth in mice ${ }^{[84]}$.

The homeostatic chemokine stromal cell-derived factor-1, CXCL12/SDF-1, which regulates cardiac and neuronal development, stem cell motility and neovascularization, was also involved in diverse tumorigenic processes ${ }^{[77]}$. The CXCL12/ SDF-1 interaction with the widely expressed tumor cell surface receptor CXCR4 initiates divergent signaling pathways which can result in a variety of responses like chemotaxis, cell survival, proliferation and metastasis ${ }^{[80]}$. CXCR4 is capable of orchestrating a complex signaling network, including the up-regulation of E-cadherin and c-myc as well as the modulation of molecules facilitating mammary epithelia cell transformation $^{[85]}$. Enhanced CXCR4 signaling was also involved in the resistance to endocrine therapy in breast cancer ${ }^{[86]}$ and in the drug resistance of $\operatorname{colon}^{[87]}$ and pancreatic cancer cells ${ }^{[88]}$. Of note, CXCR4 expression and phosphorylation has been considered a negative prognostic marker in various types of cancer including acute myelogenous leukemia and B-acute lymphoblastic leukemia, breast and colon carcinomas, as it correlated with worse prognosis and decreased survival of patients ${ }^{[86,89-92]}$. Increased levels of VEGF, the activation of nuclear factor kappa B (NF-kB) and some oncoproteins up-regulate CXCR4 expression, in particular during cancer progression ${ }^{[93,94]}$ and under hypoxic conditions ${ }^{[95]}$. CXCR4/ SDF-1 contributes to tumor progression also through the activation of tumor-associated integrin and the production of matrix metalloproteases ${ }^{[93]}$, as observed in human basal carcinoma cells ${ }^{[96]}$ and oral squamous cell carcinomas ${ }^{[97]}$. Recently, CXCR7/RDC1 has been identified as a novel receptor for CXCL12/SDF-1 and CXCL11 ${ }^{[98]}$, although its coupling to G-proteins remains controversial. CXCR7 is expressed in diverse cell types including malignant cells ${ }^{[98]}$ as well as in tumor-associated blood vessels ${ }^{[99]}$. CXCR7-dependent signals promote the growth of breast and lung tumors, enhance lung metastasis and tumor aggressiveness in prostate cancer ${ }^{[99,100]}$. Antagonists of CXCR7 prevented tumor growth in animal models, hence validating this receptor as a potential target for the development of novel anti-cancer therapeutics ${ }^{[98]}$.

\section{GPCRs activated by hormones}

Numerous hormone-activated GPCRs are overexpressed in hormone-dependent and independent tumors and trigger multiple transduction pathways, which mediate relevant biological effects in diverse cancer cells. For instance, angiotensin II (Ang-II) and bradykinin (BK) receptors are overexpressed in prostate cancer ${ }^{[101,102]}$ and mediate cell growth through $\mathrm{Ga}_{\mathrm{q}}$ and/or $\mathrm{Ga}_{13}$ which activate RhoA-dependent signaling ${ }^{[103]}$. In this regard, it was shown that Rho is involved in the androgen-like activity of androgen receptor (AR) antagonists ${ }^{[104]}$ and 
able to sensitize AR to low androgens levels ${ }^{[105]}$. On the basis of these studies, it can be assumed that GPCRs may contribute to androgen-dependent and independent growth of prostate cancer ${ }^{[103]}$. Recently, Ang-II exhibited in vitro and in vivo the potential to enhance the expression of AR in prostate cancer cells through angiotensin II type-1 receptor $(\mathrm{AT} 1 \mathrm{R})^{[106]}$. In addition, Ang-II and BK receptors have been implicated in the development, growth, angiogenesis and metastasis in a wide number of tumors ${ }^{[101,102,107-111]}$. For instance, Ang-II and BK stimulated DNA synthesis in pancreatic cancer cells ${ }^{[112]}$. In the context of this malignancy, a cross-talk between insulin/ insulin like growth factor-I (IGF-1) receptors and Ang-II and BK-activated GPCRs has been reported ${ }^{[111-114]}$. In particular, insulin induced the potentiation of Ang-II and BK-dependent signaling through the PI3K/Akt/mTOR transduction pathway ${ }^{[113]}$. Metformin, which is one of the most used drug in the treatment of type 2 diabetes, disrupted in pancreatic cancer cells the cross-talk between insulin receptor and GPCR signaling through the activation AMP kinase, which negatively regulated mTOR function ${ }^{[113]}$. Further supporting these observations, metformin prevented the growth of pancreatic cancer cells in xenograft models ${ }^{[114,115]}$. Cumulatively, these findings suggest that the cross-talk between insulin/IGF-1 receptors and GPCR-activated signaling can be considered as a mechanism involved in the development of certain tumors and a promising target for novel anti-cancer strategies.

As it concerns the renin-angiotensin system, an abundant generation of Ang-II stimulated by the angiotensin-converting enzyme (ACE) and the up-regulation of AT1R have been demonstrated in various tumors ${ }^{[110,116]}$. In this respect, ACE inhibitors and angiotensin II receptor blockers (ARBs) have recently acquired an increasing interest as chemopreventive

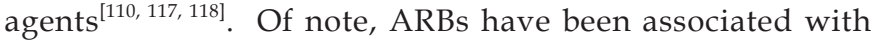
reduced cancer occurrence in patients with essential hypertension and a longer exposure to ARBs has been related with major benefits in cancer patients ${ }^{[119]}$. Nevertheless, ARBs did not show the ability to reduce considerably cancer development in a meta-analysis of randomized controlled trials ${ }^{[120]}$.

Among the GPCR family members, the gonadotropinreleasing hormone $(\mathrm{GnRH})$ receptor is a well established target in the clinical practice of cancer treatment ${ }^{[121]}$. Several antagonist analogues of GnRH have been clinically tested and numerous orally active antagonists are under development ${ }^{[121]}$. The GnRH receptor is one of the smallest GPCRs as it lacks the characteristic intracellular carboxyl-terminal domain with a very short extracellular amino-terminus. GnRH receptors are expressed not only in the pituitary and in normal peripheral tissues ${ }^{[122]}$, but also in various tumor cells like melanoma, prostate and endometrial carcinomas, leiomyomas, leiomyosarcomas, breast cancer, choriocarcinoma, epithelial and stromal tumors of the ovary ${ }^{[122,123]}$. The activation of the peripheral GnRH receptor, which is coupled to the Gi protein in uterine leiomyosarcoma, ovarian and endometrial carcinomas, decreased intracellular cAMP levels leading to a down-regulation of gene transcription and antiproliferative effects in tumor cells $^{[122]}$. Indeed, the repressive action of GnRH-I receptor on cell proliferation has been demonstrated in hormone-related tumors like prostate, breast, ovary and endometrium can$\operatorname{cer}^{[124]}$. GnRH and the cognate receptors were also involved in the stimulation of motility and invasion in ovarian cancer cells ${ }^{[125,126]}$, however several studies suggested a protective role elicited by GnRH analogues against gonadal damage during chemotherapy in diverse types of tumors ${ }^{[122]}$. On the basis of these findings, GnRH analogues are used in many endocrinedependent malignancies such as breast, endometrial, epithelial and stromal ovarian cancer. The antitumor activity of GnRH analogues was presumed to result from desensitization and/ or decrease of GnRH receptors in the pituitary, with the consequent decline in gonadotropin secretion and gonadal hormone production. Nevertheless, GnRH analogues were shown to suppress directly the growth of endometrial, ovarian, breast and prostate tumors and uterine leiomyoma ${ }^{[122,127,128]}$. Likewise, the growth of prostate cancer cells in vitro and in tumor xenografts was inhibited by activating the GnRH receptor or by GnRH receptor blockade ${ }^{[129]}$. In line with these observations, phase III trial data have demonstrated that GnRH agonists are effective and well tolerated in the treatment of hormone-sensitive prostate cancer ${ }^{[130]}$. Recently, the possibility of using GnRH analogues to carry cytotoxic agents directly to cancer cells expressing GnRH receptors has been evaluated ${ }^{[131]}$. For instance, AN-152 conjugate which is made from doxorubicin being linked to [D-Lys6]GnRH agonist, reduced the proliferation of breast, ovarian and endometrial cancer cells in vitro and in xenografted nude mice ${ }^{[132,133]}$.

Estrogens influence many physiological processes, but are also implicated in the development or progression of various types of cancer ${ }^{[134]}$. The multiple biological actions elicited by these hormones have traditionally been attributed to the classical nuclear estrogen receptor (ER) $\alpha$ and ER $\beta$, which act as ligand-activated transcription factors ${ }^{[134]}$. Surprisingly, a member of the GPCR family, GPR30/GPER, was recently shown to mediate the multifaceted actions of estrogens in different tissues including cancer cells ${ }^{[135]}$. Importantly, GPER overexpression was associated with lower survival rates in endometrial and ovarian cancer patients and with an elevated risk of developing metastases in patients with breast cancer ${ }^{[136-138]}$. GPER by transactivating EGFR triggers numerous transduction pathways including the intracellular cAMP, calcium mobilization, MAPK, PI3-K and phospholipase C activation in a variety of cell types ${ }^{[139]}$. Moreover, it has been shown that the activation of the $\mathrm{Ga}_{\mathrm{s}}$ protein by GPER is responsible for the estrogen, phyto- and xenoestrogens stimulation of adenylate cyclase and the ensuing increase in cAMP in breast cancer cells ${ }^{[140,141]}$. The signaling events upon GPER activation by both estrogens and notably ER antagonists can lead to gene transcription as well as to the growth and migration in diverse hormone-sensitive tumors like breast, endometrial and ovarian cancer ${ }^{[142-149]}$. Notably, GPER was also involved in the stimulatory effects elicited by estrogens and ER antagonists in cancer-associated fibroblasts ${ }^{[147,150]}$. 


\section{GPCRs activated by neurotransmitters}

Emerging findings support the hypothesis that the development, progression and responsiveness to treatments in most tumors is strongly influenced by an imbalance in stimulatory and inhibitory neurotransmission ${ }^{[151]}$. The neurotransmitters adrenaline and noradrenaline act as powerful regulators of numerous cellular and tissue functions and can promote tumor growth and metastases through the $\beta$-adrenergic receptors $(\beta-A R)$, which are Gs-protein coupled receptors ${ }^{[152-154]}$. For instance, noradrenaline stimulates tumor progression in diverse types of malignancies activating $\beta$-AR which in turn induces the production of VEGF, interleukin-6 (IL-6) and matrix metalloproteinases ${ }^{[153,155]}$.

As for $\beta$-adrenergic compounds ${ }^{[156]}$, the action of muscarinic acetylcholine receptors (mAchRs) on the proliferation of cancer cells is still questioned ${ }^{[157]}$. In fact, these receptors interact with distinct $G$ protein subunits triggering various cellular functions through specific downstream effectors. As it concerns M2 and M4 receptors, they interact with Gi proteins inhibiting adenylyl cyclase-dependent signaling. On the contrary, M1, M3 and M5 receptors coupled with Gq proteins activate phospholipase C, PKC and induce an increase of intracellular calcium ${ }^{[153]}$. These mAchR subtypes can protect cells from the apoptosis subsequent to DNA damage, oxidative stress and mitochondrial dysfunction ${ }^{[158]}$. Although muscarinic receptor expression was identified in cells derived from brain, breast, colon, lung, ovary, pancreas, prostate, skin, stomach and uterus malignancies ${ }^{[157]}$, only for some of these receptors a functional role has been demonstrated. In ovarian cancer the expression of muscarinic receptors was associated with reduced survival ${ }^{[159]}$, while in leukemia cells their activation resulted in increased intracellular calcium and upregulation of the oncogene $c-f{ }^{[160]}$. Activation of M3 receptor by cholinergic agonists stimulated proliferation of primary astrocytoma cells in a ERK and NF-KB dependent manner ${ }^{[157]}$. In breast cancer cells, M1 and M2 receptors were involved in angiogenesis and cell proliferation, whereas M3 receptor was associated only with cell growth ${ }^{[161]}$. Agonist binding to M3 receptor resulted in the activation of EGFR/MAPK transduction pathway, which then stimulated the proliferation in colon cancer cells $^{[162]}$.

Somatostatin receptors (SSTRs), particularly SSTR subtype 2 , were found highly expressed in many neoplastic cells and in tumoral blood vessels ${ }^{[163]}$. SST analogues decreased tumor cell growth and angiogenesis as well as stimulated apoptosis in cancer cells ${ }^{[164]}$. These findings contributed to develop various cytotoxic SST conjugates that displayed relevant anti-tumor abilities targeting selectively SSTR2-specific sites ${ }^{[165]}$.

\section{B-arrestins: novel transducers of GPCR signals}

The sensitivity of GPCRs is regulated by G protein-coupled receptor kinases (GRKs) and $\beta$-arrestins families, that are known to exert a central role in GPCR endocytosis, intracellular trafficking, desensitization and resensitization ${ }^{[166,167]}$. As it concerns $\beta$-arrestins, they can also function as molecular mediators of $\mathrm{G}$ protein-independent signaling by activating a variety of transduction proteins like Src family kinases and components of the MAPK cascades ${ }^{[166,168,169]}$. On the basis of these findings, $\beta$-arrestins were included among the signaling factors mediating the action of diverse GPCRs in cancer $^{[170]}$. For instance, $\beta$-arrestin/Ral signaling was involved in the migration and invasion of breast cancer cells induced by $\mathrm{LPA}^{[170]}$. In addition, prostaglandin E2 induced the association of prostaglandin E receptor 4 with $\beta$-arrestin 1 and c-Src, that formed a signaling complex able to induce the migration and metastasis of colorectal carcinoma cells ${ }^{[171]}$. In accordance with these data, $\beta$-arrestin 1 interacting with $\operatorname{Src}$ and $\mathrm{ET}_{\mathrm{A}} \mathrm{R}$ triggered EGFR transactivation and $\beta$-catenin phosphorylation, which stimulated invasion and metastasis in ovarian cancer cells ${ }^{[172]}$. Moreover, $\beta$-arrestin 1 forming a trimeric complex with $\mathrm{ET}_{\mathrm{A}} \mathrm{R}$ and axin contributed to the inactivation of glycogen synthase kinase (GSK)-3 and stabilization of $\beta$-catenin ${ }^{[172]}$. Collectively, these results indicate that $\beta$-arrestins exert an important role in GPCR-mediated signaling as well as a pivotal role in cancer invasion and metastasis. Novel pharmacological approaches targeting the $\beta$-arrestins pathway would provide further therapeutical opportunities in diverse types of tumors.

\section{Orphan GPCRs and cancer}

Relevant efforts were recently made in the deorphanization of the over 130 GPCRs for which ligands have not yet been identified. Some of these GPCRs have been linked to cancer development and progression on the basis of their overexpression and/or up-regulation by diverse factors ${ }^{[173-175]}$. For instance, an elevated expression of the orphan G-proteincoupled receptor GPR49 was involved in the formation and proliferation of basal cell carcinoma ${ }^{[176]}$, while GPR18 was found associated with melanoma metastases ${ }^{[177]}$. In lung, cervix, skin, urinary bladder, testis, head and neck squamous cell carcinomas were detected high levels of GPR87 $7^{[178,179]}$ for which UDP-glucose, cysteinyl-leukotrienes and LPA exhibited binding properties ${ }^{[180]}$. In breast and colon cancer cells, DNA damage has been recently found to regulate GPR87 expression in a p53-dependent manner ${ }^{[173]}$. Taken together, these results suggest that GPR87 may elicit survival and anti-apoptotic actions, while its overexpression plays a pivotal role in the development and progression of diverse types of tumors. On the contrary, GPR56 inhibited prostate cancer progression and suppressed tumor growth and metastasis in melanoma xenografs $^{[181]}$. Moreover, GPR56 inhibited VEGF production from melanoma cells and prevented melanoma angiogenesis and growth $^{[182]}$. Accordingly, the expression of GPR56 has been found inversely correlated with melanoma malignancies, suggesting its potential role in cancer development and metasta$\operatorname{sis}^{[175,182]}$.

Targeting deorphanized GPCRs also in combination with well-known anti-cancer agents would be expected to increase the effectiveness of the current therapeutical approaches. In this regard, extensive studies are required to completely decipher the biology of these receptors in order to provide the basis for the design and use of new drugs in different types of human tumors. 


\section{Concluding remarks}

Despite GPCRs form the largest superfamily of cell surface receptors involved in signal transmission, in clinical practice only few anticancer compounds are currently used in order to interfere with GPCR-mediated signaling. Although the role played by GPCRs and their ligands in tumor pathophysiology is intricate, an increasing body of evidence has recently emerged linking indubitably these molecules to the development and progression of cancer. Consequently, GPCRs and their downstream-activated effectors represent a rich source of potential drug targets for innovative strategies in tumor prevention and treatment. Next, the identification of the transduction network maps connecting several GPCR-dependent signals with other transduction pathways will facilitate further investigations regarding the biological potential of these receptors, opening in the mean time a new valuable scenario for the discovery of novel anti-cancer therapeutics. Finally, the ongoing efforts to fully characterize the numerous orphan GPCRs will certainly lead in the near future to the identification of new targets toward innovative pharmacological strategies in cancer patients.

\section{Acknowledgements}

This work was supported by Associazione Italiana per la Ricerca sul Cancro (AIRC, project No 8925/2009 and project Calabria 2011) (http://www.airc.it/), Fondazione Cassa di Risparmio di Calabria e Lucania, Ministero dell'Istruzione, dell'Università e della Ricerca (MIUR) (project PRIN 2008PK2WCW/2008) (http://www.istruzione.it/).

\section{References}

1 Pierce KL, Premont RT, Lefkowitz RJ. Seven-transmembrane receptors. Nat Rev Mol Cell Biol 2002; 3: 639-50.

2 Neves SR, Ram PT, lyengar R. G protein pathways. Science 2002; 296: 1636-9.

3 Noguchi K, Herr D, Mutoh T, Chun J. Lysophosphatidic acid (LPA) and its receptors. Curr Opin Pharmacol 2009; 9: 15-23.

4 Sanchez T, Hla T. Structural and functional characteristics of S1P receptors. J Cell Biochem 2004; 92: 913.

5 Dorsam RT, Gutkind JS. G-protein-coupled receptors and cancer. Nature Rev Cancer 2007; 7: 79-94.

6 Lappano R, Maggiolini M. G protein-coupled receptors: novel targets for drug discovery in cancer. Nat Rev Drug Discov 2011; 10: 47-60.

7 Demenais F, Mohamdi H, Chaudru V, Goldstein AM, Newton Bishop JA, Bishop DT, et al. Association of MC1R variants and host phenotypes with melanoma risk in CDKN2A mutation carriers: a GenoMEL study. J Natl Cancer Inst 2010; 102: 1568-83.

8 Voisin T, El Firar A, Fasseu M, Rouyer-Fessard C, Descatoire V, Walker $F$, et al. Aberrant expression of OX1 receptors for orexins in colon cancers and liver metastases: an openable gate to apoptosis. Cancer Res 2011; 71: 3341-51.

9 Almendro V, García-Recio S, Gascón P. Tyrosine kinase receptor transactivation associated to $\mathrm{G}$ protein-coupled receptors. Curr Drug Targets 2010; 11: 1169-80.

10 Luttrell LM. Location, location, location: activation and targeting of MAP kinases by G protein-coupled receptors. J Mol Endocrinol 2003; 30: $117-26$.

11 Gnant M, Mlineritsch B, Schippinger W, Luschin-Ebengreuth G,
Pöstlberger S, Menzel C, et al. Endocrine therapy plus zoledronic acid in premenopausal breast cancer. N Engl J Med 2009; 360: 679-91.

12 Hejna M, Schmidinger M, Raderer M. The clinical role of somatostatin analogues as antineoplastic agents: much ado about nothing? Ann Oncol 2002; 13: 653-68.

13 Mills GB, Moolenaar WH. The emerging role of lysophosphatidic acid in cancer. Nat Rev Cancer 2003; 3: 582-91.

14 Fujita T, Miyamoto S, Onoyama I, Sonoda K, Mekada E, Nakano $\mathrm{H}$. Expression of lysophosphatidic acid receptors and vascular endothelial growth factor mediating lysophosphatidic acid in the development of human ovarian cancer. Cancer Lett 2003; 192: 161-9.

15 Shida D, Watanabe T, Aoki J, Hama K, Kitayama J, Sonoda H. Aberrant expression of lysophosphatidic acid (LPA) receptors in human colorectal cancer. Lab Investigation 2004; 84: 1352-62.

16 Horak CE, Mendoza A, Vega-Valle E, Albaugh M, Graff-Cherry C, McDermott WG, et al. Nm23-H1 suppresses metastasis by inhibiting expression of the lysophosphatidic acid receptor EDG2. Cancer Res 2007; 67: 11751-9.

17 Boucharaba A, Serre CM, Guglielmi J, Bordet JC, Clezardin P, Peyruchaud 0 . The type 1 lysophosphatidic acid receptor is a target for therapy in bone metastases. Proc Natl Acad Sci U S A 2006; 103: 9643-8.

$18 \mathrm{Kim} \mathrm{JH}$, Adelstein RS. LPA(1)-induced migration requires nonmuscle myosin II light chain phosphorylation in breast cancer cells. J Cell Physiol 2011; 226: 2881-93.

19 Liu S, Umezu-Goto M, Murph M, Lu Y, Liu W, Zhang F, et al. Expression of autotaxin and lysophosphatidic acid receptors increases mammary tumorigenesis, invasion, and metastases. Cancer Cell 2009; 15: 539-50.

20 Bian D, Su S, Mahanivong C, Cheng RK, Han Q, Pan ZK, et al. Lysophosphatidic acid stimulates ovarian cancer cell migration via a RasMEK kinase 1 pathway. Cancer Res 2004; 64: 4209-17.

21 Saunders JA, Rogers LC, Klomsiri C, Poole LB, Daniel LW. Reactive oxygen species mediate lysophosphatidic acid induced signaling in ovarian cancer cells. Free Radic Biol Med 2010; 49: 2058-67.

22 Chen $\mathrm{H}, \mathrm{Wu}$ X, Pan ZK, Huang S. Integrity of SOS1/EPS8/ABI1 tricomplex determines ovarian cancer metastasis. Cancer Res 2010; 70: 9979-90.

23 Li H, Wang D, Zhang H, Kirmani K, Zhao Z, Steinmetz R, et al. Lysophosphatidic acid stimulates cell migration, invasion, and colony formation as well as tumorigenesis/metastasis of mouse ovarian cancer in immunocompetent mice. Mol Cancer Ther 2009; 8: 1692701.

24 Oyesanya RA, Greenbaum S, Dang D, Lee Z, Mukherjee A, Wu J, et al. Differential requirement of the epidermal growth factor receptor for $\mathrm{G}$ protein-mediated activation of transcription factors by lysophosphatidic acid. Mol Cancer 2010; 9: 8.

25 Snider AJ, Zhang Z, Xie Y, Meier KE. Epidermal growth factor increases lysophosphatidic acid production in human ovarian cancer cells: roles for phospholipase $D_{2}$ and receptor transactivation. Am J Physiol Cell Physiol 2010; 298: C163-70.

26 Jeon ES, Lee IH, Heo SC, Shin SH, Choi YJ, Park JH, et al. Mesenchymal stem cells stimulate angiogenesis in a murine xenograft model of A549 human adenocarcinoma through an LPA1 receptordependent mechanism. Biochim Biophys Acta 2010; 1801: 120513.

27 Xu X, Prestwich GD. Inhibition of tumor growth and angiogenesis by a lysophosphatidic acid antagonist in an engineered three-dimensional lung cancer xenograft model. Cancer 2010; 116: 1739-50. 
28 Pyne NJ, Pyne S. Sphingosine 1-phosphate and cancer. Nat Rev Cancer 2010; 10: 489-503.

29 Goetzl EJ, Dolezalova H, Kong Y, Zeng L. Dual mechanisms for lysophospholipid induction of proliferation of human breast carcinoma cells. Cancer Res 1999; 59: 4732-7.

30 Yamashita H, Kitayama J, Shida D, Yamaguchi H, Mori K, Osada M, et al. Sphingosine 1-phosphate receptor expression profile in human gastric cancer cells: differential regulation on the migration and proliferation. J Surg Res 2006; 130: 80-7.

31 Bergelin N, Löf C, Balthasar S, Kalhori V, Törnquist K. S1P1 and VEGFR-2 form a signaling complex with extracellularly regulated kinase $1 / 2$ and protein kinase $\mathrm{C}$-alpha regulating $\mathrm{ML}-1$ thyroid carcinoma cell migration. Endocrinology 2010; 151: 2994-3005.

32 Lepley D, Paik JH, Hla T, Ferrer F. The G protein-coupled receptor S1P2 regulates Rho/Rho kinase pathway to inhibit tumor cell migration. Cancer Res 2005; 65: 3788-95.

33 Lee H, Deng J, Kujawski M, Yang C, Liu Y, Herrmann A, et al. STAT3induced S1PR1 expression is crucial for persistent STAT3 activation in tumors. Nat Med 2010; 16: 1421-8.

34 Li MH, Sanchez T, Yamase H, Hla T, Oo ML, Pappalardo A, et al. S1P/ S1P1 signaling stimulates cell migration and invasion in Wilms tumor. Cancer Lett 2009; 276: 171-9.

35 Young N, Pearl DK, Van Brocklyn JR. Sphingosine-1-phosphate regulates glioblastoma cell invasiveness through the urokinase plasminogen activator system and CCN1/Cyr61. Mol Cancer Res 2009; 7: 23-32.

36 Arikawa K, Takuwa N, Yamaguchi H, Sugimoto N, Kitayama J, Nagawa $\mathrm{H}$, et al. Ligand-dependent inhibition of B16 melanoma cell migration and invasion via endogenous S1P2 G protein-coupled receptor. Requirement of inhibition of cellular RAC activity. J Biol Chem 2003; 278: 32841-51.

37 Takuwa Y, Du W, Qi X, Okamoto Y, Takuwa N, Yoshioka K. Roles of sphingosine-1-phosphate signaling in angiogenesis. World J Biol Chem 2010; 1: 298-306.

38 Visentin B, Vekich JA, Sibbald BJ, Cavalli AL, Moreno KM, Matteo RG, et al. Validation of an anti-sphingosine-1-phosphate antibody as a potential therapeutic in reducing growth, invasion, and angiogenesis in multiple tumor lineages. Cancer Cell 2006; 9: 225-38.

39 Chae SS, Paik JH, Furneaux H, Hla T. Requirement for sphingosine 1-phosphate receptor-1 in tumor angiogenesis demonstrated by in vivo RNA interference. J Clin Invest 2004; 114: 1082-9.

40 Du W, Takuwa N, Yoshioka K, Okamoto Y, Gonda K, Sugihara K, et al. $\mathrm{S} 1 \mathrm{P}(2)$, the G protein-coupled receptor for sphingosine-1-phosphate, negatively regulates tumor angiogenesis and tumor growth in vivo in mice. Cancer Res 2010; 70: 772-81.

41 Bagnato A, Rosanò L. The endothelin axis in cancer. Int J Biochem Cell Biol 2008; 40: 1443-51.

42 Arun C, London NJ, Hemingway DM. Prognostic significance of elevated endothelin-1 levels in patients with colorectal cancer. Int J Biol Markers 2004; 19: 32-7.

43 Bagnato A, Loizidou M, Pflug BR, Curwen J, Growcott J. Role of the endothelin axis and its antagonists in the treatment of cancer. $\mathrm{Br} J$ Pharmacol 2011; 163: 220-33.

44 Rosanò L, Cianfrocca R, Spinella F, Di Castro V, Nicotra MR, Lucidi A, et al. Acquisition of chemoresistance and EMT phenotype is linked with activation of the endothelin A receptor pathway in ovarian carcinoma cells. Clin Cancer Res 2011; 17: 2350-60.

45 Thomas SM, Grandis JR, Wentzel AL, Gooding WE, Lui VW, Siegfried JM. Gastrin-releasing peptide receptor mediates activation of the epidermal growth factor receptor in lung cancer cells. Neoplasia 2005; 7: 426-31.
46 Lui VW, Thomas SM, Zhang Q, Wentzel AL, Siegfried JM, Li JY, et al. Mitogenic effects of gastrin-releasing peptide in head and neck squamous cancer cells are mediated by activation of the epidermal growth factor receptor. Oncogene 2003; 22: 6183-93.

47 Hohla F, Schally AV. Targeting gastrin releasing peptide receptors: New options for the therapy and diagnosis of cancer. Cell Cycle 2010; 9: 1738-41.

48 Mu L, Honer M, Becaud J, Martic M, Schubiger PA, Ametamey SM, et al. In vitro and in vivo characterization of novel ${ }^{18} \mathrm{~F}$-labeled bombesin analogues for targeting GRPR-positive tumors. Bioconjug Chem 2010; 21: 1864-71.

49 Honer M, Mu L, Stellfeld T, Graham K, Martic M, Fischer CR, et al. ${ }^{18} \mathrm{~F}$-labeled bombesin analog for specific and effective targeting of prostate tumors expressing gastrin-releasing peptide receptors. J Nucl Med 2011; 52: 270-8.

50 Coughlin SR. Thrombin signalling and protease-activated receptors. Nature 2000; 407: 258-64.

51 Yang E, Boire A, Agarwal A, Nguyen N, O'Callaghan K, Tu P, et al. Blockade of PAR1 signaling with cell-penetrating pepducins inhibits Akt survival pathways in breast cancer cells and suppresses tumor survival and metastasis. Cancer Res 2009; 69: 6223-31.

52 Wysoczynski M, Liu R, Kucia M, Drukala J, Ratajczak Mz. Thrombin regulates the metastatic potential of human rhabdomyosarcoma cells: distinct role of PAR1 and PAR3 signaling. Mol Cancer Res 2010; 8: 677-90.

53 García-López MT, Gutiérrez-Rodríguez M, Herranz R. Thrombinactivated receptors: promising targets for cancer therapy? Curr Med Chem 2010; 17: 109-28.

54 Arora P, Cuevas BD, Russo A, Johnson GL, Trejo J. Persistent transactivation of EGFR and ErbB2/HER2 by protease-activated receptor-1 promotes breast carcinoma cell invasion. Oncogene 2008; 27 : 4434-45.

55 Villares GJ, Zigler M, Dobroff AS, Wang H, Song R, Melnikova VO, et al. Protease activated receptor-1 inhibits the Maspin tumorsuppressor gene to determine the melanoma metastatic phenotype. Proc Natl Acad Sci U S A 2011; 108: 626-31.

56 Boire A, Covic L, Agarwal A, Jacques S, Sherifi S, Kuliopulos A. PAR1 is a matrix metalloprotease-1 receptor that promotes invasion and tumorigenesis of breast cancer cells. Cell 2005; 120: 303-13.

57 Agarwal A, Tressel SL, Kaimal R, Balla M, Lam FH, Covic L, et al. Identification of a metalloprotease-chemokine signaling system in the ovarian cancer microenvironment: implications for antiangiogenic therapy. Cancer Res 2010; 70: 5880-90.

58 Clevers $\mathrm{H}$. Wnt/beta-catenin signaling in development and disease. Cell 2006; 127: 469-80.

$59 \mathrm{Hu}$ T, Li C. Convergence between Wnt- $\beta$-catenin and EGFR signaling in cancer. Mol Cancer 2010; 9: 236.

60 Jones KA, Kemp CR. Wnt-induced proteolytic targeting. Genes Dev 2008; 22: 3077-81.

61 Ojalvo LS, Whittaker CA, Condeelis JS, Pollard JW. Gene expression analysis of macrophages that facilitate tumor invasion supports a role for Wnt-signaling in mediating their activity in primary mammary tumors. J Immunol 2010; 184: 702-12.

62 Lai SL, Chien AJ, Moon RT. Wnt/Fz signaling and the cytoskeleton: potential roles in tumorigenesis. Cell Res 2009; 19: 532-45.

63 Nambotin SB, Lefrancois L, Sainsily X, Berthillon P, Kim M, Wands $J R$, et al. Pharmacological inhibition of Frizzled-7 displays anti-tumor properties in hepatocellular carcinoma. J Hepatol 2011; 54: 28899.

64 Yang L, Wu X, Wang Y, Zhang K, Wu J, Yuan YC, et al. FZD7 has a critical role in cell proliferation in triple negative breast cancer. 
Oncogene 2011; 30: 4437-46.

65 Jin X, Jeon HY, Joo KM, Kim JK, Jin J, Kim SH, et al. Frizzled 4 regulates stemness and invasiveness of migrating glioma cells established by serial intracranial transplantation. Cancer Res 2011; 71: 3066-75.

66 Scales SJ, de Sauvage FJ. Mechanisms of Hedgehog pathway activation in cancer and implications for therapy. Trends Pharmacol Sci 2009; 30: 303-12.

67 Teglund S, Toftgard R. Hedgehog beyond medulloblastoma and basal cell carcinoma. Biochim Biophys Acta 2010; 1805: 181-208.

68 Singh S, Wang Z, Liang Fei D, Black KE, Goetz JA, Tokhunts R, et al. Hedgehog-producing cancer cells respond to and require autocrine Hedgehog activity. Cancer Res 2011; 71: 4454-63.

69 Merchant AA, Matsui W. Targeting Hedgehog-a cancer stem cell pathway. Clin Cancer Res 2010; 16: 3130-40.

70 Tang T, Tang JY, Li D, Reich M, Callahan CA, Fu L, et al. Targeting superficial or nodular Basal cell carcinoma with topically formulated small molecule inhibitor of smoothened. Clin Cancer Res 2011; 17: 3378-87.

71 Metcalfe C, de Sauvage FJ. Hedgehog fights back: mechanisms of acquired resistance against Smoothened antagonists. Cancer Res 2011; 71: 5057-61.

72 Dijkgraaf GJ, Alicke B, Weinmann L, Januario T, West K, Modrusan Z, et al. Small molecule inhibition of GDC-0449 refractory smoothened mutants and downstream mechanisms of drug resistance. Cancer Res 2011; 71: 435-44.

73 Tao H, Jin Q, Koo DI, Liao X, Englund NP, Wang Y, et al. Small molecule antagonists in distinct binding modes inhibit drug-resistant mutant of smoothened. Chem Biol 2011; 18: 432-7.

74 Mazumdar T, DeVecchio J, Shi T, Jones J, Agyeman A, Houghton JA. Hedgehog signaling drives cellular survival in human colon carcinoma cells. Cancer Res 2011; 71: 1092-102.

75 Desch P, Asslaber D, Kern D, Schnidar H, Mangelberger D, Alinger $\mathrm{B}$, et al. Inhibition of GLI, but not Smoothened, induces apoptosis in chronic lymphocytic leukemia cells. Oncogene 2010; 29: 4885-95.

76 Kim J, Tang JY, Gong R, Kim J, Lee JJ, Clemons KV, et al. Itraconazole, a commonly used antifungal that inhibits Hedgehog pathway activity and cancer growth. Cancer Cell 2010; 17: 388-99.

77 Vandercappellen J, Van Damme J, Struyf S. The role of CXC chemokines and their receptors in cancer. Cancer Lett 2008; 267: 22644.

78 Thelen M. Dancing to the tune of chemokines. Nat Immunol 2001; 2: 129-34.

79 Kamohara H, Takahashi M, Ishiko T, Ogawa M, Baba H. Induction of interleukin-8 (CXCL-8) by tumor necrosis factor-alpha and leukemia inhibitory factor in pancreatic carcinoma cells: Impact of CXCL-8 as an autocrine growth factor. Int J Oncol 2007; 31: 627-32.

80 Balkwill F. Cancer and the chemokine network. Nat Rev Cancer 2004; 4: 540-50.

81 Yanagawa J, Walser TC, Zhu LX, Hong L, Fishbein MC, Mah V, et al. Snail promotes CXCR2 ligand-dependent tumor progression in nonsmall cell lung carcinoma. Clin Cancer Res 2009; 15: 6820-9.

82 Matsuo Y, Raimondo M, Woodward TA, Wallace MB, Gill KR, Tong Z, et al. CXC-chemokine/CXCR2 biological axis promotes angiogenesis in vitro and in vivo in pancreatic cancer. Int J Cancer 2009; 125: 1027-37.

$83 \mathrm{Xu} \mathrm{J}$, Zhang $\mathrm{C}$, He Y, Wu H, Wang Z, Song W, et al. Lymphatic endothelial cell-secreted CXCL1 stimulates lymphangiogenesis and metastasis of gastric cancer. Int J Cancer 2011. doi: 10.1002/ ijc. 26035.

84 Singh S, Nannuru KC, Sadanandam A, Varney ML, Singh RK. CXCR1 and CXCR2 enhances human melanoma tumourigenesis, growth and invasion. Br J Cancer 2009; 100: 1638-46.

85 Su H, Sobrino Najul EJ, Toth TA, Ng CM, Lelievre SA, Fred M, et al. Chemokine receptor CXCR4-mediated transformation of mammary epithelial cells by enhancing multiple RTKs expression and deregulation of the p53/MDM2 axis. Cancer Lett 2011; 307: 132-40.

86 Rhodes LV, Short SP, Neel NF, Salvo VA, Zhu Y, Elliott S, et al. Cytokine receptor CXCR4 mediates estrogen-independent tumorigenesis, metastasis, and resistance to endocrine therapy in human breast cancer. Cancer Res 2011; 71: 603-13.

87 Dessein AF, Stechly L, Jonckheere N, Dumont P, Monté D, Leteurtre $\mathrm{E}$, et al. Autocrine induction of invasive and metastatic phenotypes by the MIF-CXCR4 axis in drug-resistant human colon cancer cells. Cancer Res 2010; 70: 4644-54.

88 Singh S, Srivastava SK, Bhardwaj A, Owen LB, Singh AP. CXCL12CXCR4 signalling axis confers gemcitabine resistance to pancreatic cancer cells: a novel target for therapy. Br J Cancer 2010; 103: 1671-9.

89 Li YM, Pan Y, Wei Y, Cheng X, Zhou BP, Tan M, et al. CXCR4 is a prognostic marker in acute myelogenous leukemia. Cancer Cell 2004; 6: 459-69.

90 Kim J, Takeuchi H, Lam ST, Turner RR, Wang HJ, Kuo C, et al. Chemokine receptor CXCR4 expression in colorectal cancer patients increases the risk for recurrence and for poor survival. J Clin Oncol 2005; 23: 2744-53.

91 Konoplev S, Jorgensen JL, Thomas DA, Lin E, Burger J, Kantarjian $\mathrm{HM}$, et al. Phosphorylated CXCR4 is associated with poor survival in adults with B-acute lymphoblastic leukemia. Cancer 2011; 117: 4689-95.

92 Rombouts EJ, Pavic B, Lowenberg B, Ploemacher RE. Relation between CXCR-4 expression, Flt3 mutations, and unfavorable prognosis of adult acute myeloid leukemia. Blood 2004; 104: 5507.

93 Furusato B, Mohamed A, Uhlén M, Rhim JS. CXCR4 and cancer. Pathol Int 2010; 60: 497-505.

94 Miyanishi N, Suzuki Y, Simizu S, Kuwabara Y, Banno K, Umezawa K. Involvement of autocrine CXCL12/CXCR4 system in the regulation of ovarian carcinoma cell invasion. Biochem Biophys Res Commun 2010; 403: 154-9.

95 Schutyser E, Su Y, Yu Y, Gouwy M, Zaja-Milatovic S, Van Damme J, et al. Hypoxia enhances CXCR4 expression in human microvascular endothelial cells and human melanoma cells. Eur Cytokine Netw 2007; 18: 59-70.

96 Chu CY, Cha ST, Chang CC, Hsiao CH, Tan CT, Lu YC, et al. Involvement of matrix metalloproteinase-13 in stromal-cell-derived factor 1 alphadirected invasion of human basal cell carcinoma cells. Oncogene 2007; 26: 2491-501.

97 Yu T, Wu Y, Helman JI, Wen Y, Wang C, Li L. CXCR4 promotes oral squamous cell carcinoma migration and invasion through inducing expression of MMP-9 and MMP-13 via the ERK signaling pathway. Mol Cancer Res 2011; 9: 161-72.

98 Burns JM, Summers BC, Wang Y, Melikian A, Berahovich R, Miao Z, et al. A novel chemokine receptor for SDF-1 and I-TAC involved in cell survival, cell adhesion, and tumor development. J Exp Med 2006; 203: 2201-13.

99 Miao Z, Luker KE, Summers BC, Berahovich R, Bhojani MS, Rehemtulla A, et al. CXCR7 (RDC1) promotes breast and lung tumor growth in vivo and is expressed on tumor-associated vasculature. Proc Natl Acad Sci U S A 2007; 104: 15735-40.

100 Wang J, Shiozawa Y, Wang J, Wang Y, Jung Y, Pienta KJ, et al. The role of CXCR7/RDC1 as a chemokine receptor for CXCL12/SDF-1 in 
prostate cancer. J Biol Chem 2008; 283: 4283-94.

101 Uemura H, Hoshino K, Kubota Y. Engagement of renin-angiotensin system in prostate cancer. Curr Cancer Drug Targets 2011; 11: 442-50.

102 Taub JS, Guo R, Leeb-Lundberg LM, Madden JF, Daaka Y. Bradykinin receptor subtype 1 expression and function in prostate cancer. Cancer Res 2003; 63: 2037-41.

103 Daaka Y. G proteins in cancer: the prostate cancer paradigm. Sci STKE 2004; 2004: re2.

104 Metzger E, Müller JM, Ferrari S, Buettner R, Schüle R. A novel inducible transactivation domain in the androgen receptor: implications for PRK in prostate cancer. EMBO J 2003; 22: 270-80.

105 Müller JM, Isele U, Metzger E, Rempel A, Moser M, Pscherer A, et al. $\mathrm{FHL2}$, a novel tissue-specific coactivator of the androgen receptor. EMBO J 2000; 19: 359-69.

106 Hoshino K, Ishiguro H, Teranishi Jl, Yoshida SI, Umemura S, Kubota $\mathrm{Y}$, et al. Regulation of androgen receptor expression through angiotensin II type 1 receptor in prostate cancer cells. Prostate 2011; 71: 964-75.

107 Deshayes F, Nahmias C. Angiotensin receptors: a new role in cancer? Trends Endocrinol Metab 2005; 16: 293-9.

108 Lau ST, Leung PS. Role of the RAS in pancreatic cancer. Curr Cancer Drug Targets 2011; 11: 412-20.

109 Ino K, Shibata K, Yamamoto E, Kajiyama H, Nawa A, Mabuchi Y, et al. Role of the renin-angiotensin system in gynecologic cancers. Curr Cancer Drug Targets 2011; 11: 405-11.

110 Molina L, Matus CE, Astroza A, Pavicic F, Tapia E, Toledo C, et al. Stimulation of the bradykinin $\mathrm{B}(1)$ receptor induces the proliferation of estrogen-sensitive breast cancer cells and activates the ERK1/2 signaling pathway. Breast Cancer Res Treat 2009; 118: 499-510.

111 Lu DY, Leung YM, Huang SM, Wong KL. Bradykinin-induced cell migration and COX-2 production mediated by the bradykinin B1 receptor in glioma cells. J Cell Biochem 2010; 110: 141-50.

112 Guha S, Lunn JA, Santiskulvong C, Rozengurt E. Neurotensin stimulates protein kinase C-dependent mitogenic signaling in human pancreatic carcinoma cell line PANC-1. Cancer Res 2003; 63: 2379-87.

113 Kisfalvi K, Rey O, Young SH, Sinnett-Smith J, Rozengurt E. Insulin potentiates $\mathrm{Ca}^{2+}$ signaling and phosphatidylinositol 4,5-bisphosphate hydrolysis induced by Gq protein-coupled receptor agonists through an mTOR-dependent pathway. Endocrinology 2007; 148: 3246-57.

114 Rozengurt E, Sinnett-Smith J, Kisfalvi K. Crosstalk between insulin/ insulin-like growth factor-1 receptors and $G$ protein-coupled receptor signaling systems: a novel target for the antidiabetic drug metformin in pancreatic cancer. Clin Cancer Res 2010; 16: 2505-11.

115 Kisfalvi K, Eibl G, Sinnett-Smith J, Rozengurt E. Metformin disrupts crosstalk between $\mathrm{G}$ protein-coupled receptor and insulin receptor signaling systems and inhibits pancreatic cancer growth. Cancer Res 2009; 69: 6539-45.

116 Dolley-Hitze T, Jouan F, Martin B, Mottier S, Edeline J, Moranne O, et al. Angiotensin-2 receptors (AT1-R and AT2-R), new prognostic factors for renal clear-cell carcinoma? Br J Cancer 2010; 103: 1698-705.

117 Arrieta O, Guevara P, Escobar E, Garcia-Navarrete R, Pineda B, Sotelo J. Blockage of angiotensin II type I receptor decreases the synthesis of growth factors and induces apoptosis in $\mathrm{C} 6$ cultured cells and C6 rat glioma. Br J Cancer 2005; 92: 1247-52.

118 Kosugi M, Miyajima A, Kikuchi E, Horiguchi Y, Murai M. Angiotensin II type 1 receptor antagonist candesartan as an angiogenic inhibitor in a xenograft model of bladder cancer. Clin Cancer Res 2006; 12: 2888-93.

119 Huang CC, Chan WL, Chen YC, Chen TJ, Lin SJ, Chen JW, et al.
Angiotensin II receptor blockers and risk of cancer in patients with systemic hypertension. Am J Cardiol 2011; 107: 1028-33.

120 Sipahi I, Debanne SM, Rowland DY, Simon DI, Fang JC. Angiotensinreceptor blockade and risk of cancer: meta-analysis of randomised controlled trials. Lancet Oncol 2010; 11: 627-36.

121 Pommerville PJ, de Boer JG. GnRH antagonists in the treatment of advanced prostate cancer. Can J Urol 2010; 17: 5063-70.

122 Yu B, Ruman J, Christman G. The role of peripheral gonadotropinreleasing hormone receptors in female reproduction. Fertil Steril 2011; 95: 465-73.

123 Halmos G, Arencibia JM, Schally AV, Davis R, Bostwick DG. High incidence of receptors for luteinizing hormone-releasing hormone (LHRH) and LHRH receptor gene expression in human prostate cancers. J Urol 2001; 163: 623-9.

124 Gründker C, Günthert AR, Westphalen S, Emons G. Biology of the gonadotropin-releasing hormone system in gynecological cancers. Eur J Endocrinol 2002; 146: 1-14.

125 Cheung LW, Mak AS, Cheung AN, Ngan HY, Leung PC, Wong AS. $\mathrm{P}$-cadherin cooperates with insulin-like growth factor-1 receptor to promote metastatic signaling of gonadotropin-releasing hormone in ovarian cancer via p120 catenin. Oncogene 2011; 30: 2964-74.

126 Ling Poon S, Lau MT, Hammond GL, Leung PC. Gonadotropinreleasing hormone-II increases membrane type I metalloproteinase production via beta-catenin signaling in ovarian cancer cells. Endocrinology 2011; 152: 764-72.

127 Schubert A, Hawighorst T, Emons G, Gründker C. Agonists and antagonists of $\mathrm{GnRH}-\mathrm{I}$ and -II reduce metastasis formation by triplenegative human breast cancer cells in vivo. Breast Cancer Res Treat 2011; 130: 783-90

128 Kraus S, Levy G, Hanoch T, Naor Z, Seger R. Gonadotropin releasing hormone induces apoptosis of prostate cancer cells: Role of c-Jun $\mathrm{NH}_{2}$-terminal kinase, protein kinase $\mathrm{B}$, and extracellular signalregulated kinase pathways. Cancer Res 2004; 64: 5736-44.

129 Kim DK, Yang JS, Maiti K, Hwang JI, Kim K, Seen D, et al. A gonadotropin releasing hormone-II antagonist induces autophagy of prostate cancer cells. Cancer Res 2009; 69: 923-31.

130 Van Poppel H. Evaluation of degarelix in the management of prostate cancer. Cancer Manag Res 2010; 2: 39-52.

131 Schally AV, Varga JL. Antagonists of growth hormone-releasing hormone in oncology. Comb Chem High Throughput Screen 2006; 9: 163-70.

132 Szepeshazi K, Schally AV, Nagy A. Effective treatment of advanced estrogen-independent MXT mouse mammary cancers with targeted cytotoxic LH-RH analogs. Breast Cancer Res Treat 1999; 56: $267-$ 76.

133 Grundker C, Volker P, Griesinger F, Ramaswamy A, Nagy A, Schally AV, et al. Antitumor effects of the cytotoxic luteinizing hormone-releasing hormone analog AN-152 on human endometrial and ovarian cancers xenografted into nude mice. Am J Obstet Gynecol 2002; 187: 52837.

134 Chen GG, Zeng Q, Tse GM. Estrogen and its receptors in cancer. Med Res Rev 2008; 28: 954-74.

135 Maggiolini M, Picard D. The unfolding stories of GPR30, a new membrane bound estrogen receptor. J Endocrinol 2010; 204: 10514.

136 Smith HO, Leslie KK, Singh M, Qualls CR, Revankar CM, Joste NE, et al. GPR30: a novel indicator of poor survival for endometrial carcinoma. Am J Obstet Gynecol 2007; 196: 386.e1-9.

137 Smith HO, Arias-Pulido H, Kuo DY, Howard T, Qualls CR, Lee SJ, et al. GPR30 predicts poor survival for ovarian cancer. Gynecol Oncol 2009; 114: 465-71. 
138 Filardo EJ, Graeber CT, Quinn JA, Resnick MB, Giri D, DeLellis RA, et al. Distribution of GPR30, a seven membrane-spanning estrogen receptor, in primary breast cancer and its association with clinicopathologic determinants of tumor progression. Clin Cancer Res 2006; 12: 6359-66.

139 Prossnitz ER, Maggiolini M. Mechanisms of estrogen signaling and gene expression via GPR30. Mol Cell Endocrinol 2009; 308: 32-8.

140 Thomas P, Pang Y, Filardo EJ, Dong J. Identity of an estrogen membrane receptor coupled to a $\mathrm{G}$ protein in human breast cancer cells. Endocrinology 2005; 146: 624-32.

141 Thomas P, Dong J. Binding and activation of the seven-transmembrane estrogen receptor GPR30 by environmental estrogens: a potential novel mechanism of endocrine disruption. J Steroid Biochem Mol Biol 2006; 102: 175-9.

142 Maggiolini M, Vivacqua A, Fasanella G, Recchia AG, Sisci D, Pezzi $\mathrm{V}$, et al. The G protein coupled receptor GPR30 mediates $\mathrm{C}$-fos upregulation by $17 \beta$-estradiol and phytoestrogens in breast cancer cells. J Biol Chem 2004; 279: 27008-16.

143 Vivacqua A, Bonofiglio D, Recchia AG, Musti AM, Picard D, Andò S, et al. The G protein-coupled receptor GPR30 mediates the proliferative effects induced by $17 \beta$-estradiol and hydroxytamoxifen in endometrial cancer cells. Mol Endocrinol 2006; 20: 631-46.

144 Albanito L, Madeo A, Lappano R, Vivacqua A, Rago V, Carpino A, et al. G protein-coupled receptor 30 (GPR30) mediates gene expression changes and growth response to 17 beta-estradiol and selective GPR30 ligand G-1 in ovarian cancer cells. Cancer Res 2007; 67: 1859-66.

145 Albanito L, Lappano R, Madeo A, Chimento A, Prossnitz ER, Cappello AR, et al. G-protein-coupled receptor 30 and estrogen receptor-alpha are involved in the proliferative effects induced by atrazine in ovarian cancer cells. Environ Health Perspect 2008; 116: 1648-55.

146 Albanito L, Sisci D, Aquila S, Brunelli E, Vivacqua A, Madeo A, et al. Epidermal growth factor induces $G$ protein-coupled receptor 30 expression in estrogen receptor-negative breast cancer cells. Endocrinology 2008; 149: 3799-808.

147 Pandey DP, Lappano R, Albanito L, Madeo A, Maggiolini M, Picard D. Estrogenic GPR30 signalling induces proliferation and migration of breast cancer cells through CTGF. EMBO J 2009; 28: 523-32.

148 Vivacqua A, Lappano R, De Marco P, Sisci D, Aquila S, De Amicis F, et al. G protein-coupled receptor 30 expression is upregulated by EGF and TGFalpha in estrogen receptor alpha-positive cancer cells. Mol Endocrinol 2009; 11: 1815-26.

149 Lappano R, Rosano C, De Marco P, De Francesco EM, Pezzi V, Maggiolini M. Estriol acts as a GPR30 antagonist in estrogen receptor-negative breast cancer cells. Mol Cell Endocrinol 2010; 320: 162-70.

150 Madeo A, Maggiolini M. Nuclear alternate estrogen receptor GPR30 mediates 17 beta-estradiol-induced gene expression and migration in breast cancer-associated fibroblasts. Cancer Res 2010; 70: 603646.

151 Schuller HM. Neurotransmission and cancer: implications for prevention and therapy. Anticancer Drugs 2008; 19: 655-71.

152 Thaker PH, Han LY, Kamat AA, Arevalo JM, Takahashi R, Lu C, et al. Chronic stress promotes tumor growth and angiogenesis in a mouse model of ovarian carcinoma. Nat Med 2006; 12: 939-44.

153 Yang EV, Kim SJ, Donovan EL, Chen M, Gross AC, Webster Marketon $\mathrm{JI}$, et al. Norepinephrine upregulates VEGF, IL-8, and IL-6 expression in human melanoma tumor cell lines: implications for stress-related enhancement of tumor progression. Brain Behav Immun 2009; 23: 267-75.

154 Sloan EK, Priceman SJ, Cox BF, Yu S, Pimentel MA, Tangkanangnukul
V, et al. The sympathetic nervous system induces a metastatic switch in primary breast cancer. Cancer Res 2010, 70: 7042-52.

155 Lutgendorf SK, Cole S, Costanzo E, Bradley S, Coffin J, Jabbari S, et al. Stress-related mediators stimulate vascular endothelial growth factor secretion by two ovarian cancer cell lines. Clin Cancer Res 2003; 9: 4514-21.

156 Lüthy IA, Bruzzone A, Piñero CP, Castillo LF, Chiesa IJ, Vázquez SM, et al. Adrenoceptors: non conventional target for breast cancer? Curr Med Chem 2009; 16: 1850-62.

157 Shah N, Khurana S, Cheng K, Raufman JP. Muscarinic receptors and ligands in cancer. Am J Physiol Cell Physiol 2009; 296: C221-32.

158 De Sarno P, Shestopal SA, King TD, Zmijewska A, Song L, Jope RS. Muscarinic receptor activation protects cells from apoptotic effects of DNA damage, oxidative stress, and mitochondrial inhibition. J Biol Chem 2003; 278: 11086-93.

159 Oppitz M, Mobus V, Brock S, Drews U. Muscarinic receptors in cell lines from ovarian carcinoma: negative correlation with survival of patients. Gynecol Oncol 2002; 85: 159-64.

160 Kawashima K, Fujii T. Extraneuronal cholinergic system in lymphocytes. Pharmacol Ther 2000; 86: 29-48.

161 Español AJ, de la Torre E, Fiszman GL, Sales ME. Role of nonneuronal cholinergic system in breast cancer progression. Life Sci 2007; 80: 2281-5.

162 Cheng K, Zimniak P, Raufman JP. Transactivation of the epidermal growth factor receptor mediates cholinergic agonist-induced proliferation of $\mathrm{H} 508$ human colon cancer cells. Cancer Res 2003; 63: 6744-50.

163 Reubi JC, Waser B, Schaer JC, Laissue JA. Somatostatin receptor sst1-sst5 expression in normal and neoplastic human tissues using receptor autoradiography with subtype-selective ligands. Eur J Nucl Med 2001; 28: 836-46.

164 Dizeyi N, Konrad L, Bjartell A, Wu H, Gadaleanu V, Hansson J, et al. Localization and mRNA expression of somatostatin receptor subtypes in human prostatic tissue and prostate cancer cell lines. Urol Oncol 2002; 7: 91-8.

165 Sun LC, Coy DH. Somatostatin receptor-targeted anti-cancer therapy. Curr Drug Deliv 2011; 8: 2-10.

166 Luttrell LM, Lefkowitz RJ. The role of beta-arrestins in the termination and transduction of G-protein-coupled receptor signals. J Cell Sci 2002; 115: 455-65.

167 Ribas C, Penela P, Murga C, Salcedo A, García-Hoz C, Jurado-Pueyo $\mathrm{M}$, et al. The G protein-coupled receptor kinase (GRK) interactome: role of GRKs in GPCR regulation and signaling. Biochim Biophys Acta 2007; 1768: 913-22.

168 Lefkowitz RJ, Shenoy SK. Transduction of receptor signals by betaarrestins. Science 2005; 308: 512-7.

169 Rakesh K, Yoo B, Kim IM, Salazar N, Kim KS, Rockman HA. betaArrestin-biased agonism of the angiotensin receptor induced by mechanical stress. Sci Signal 2010; 3: ra46.

170 Li TT, Alemayehu M, Aziziyeh Al, Pape C, Pampillo M, Postovit LM, et al. Beta-arrestin/Ral signaling regulates lysophosphatidic acidmediated migration and invasion of human breast tumor cells. Mol Cancer Res 2009; 7: 1064-77.

171 Buchanan FG, Gorden DL, Matta P, Shi Q, Matrisian LM, DuBois RN. Role of beta-arrestin 1 in the metastatic progression of colorectal cancer. Proc Natl Acad Sci U S A 2006; 103: 1492-7.

172 Rosanò L, Cianfrocca R, Masi S, Spinella F, Di Castro V, Biroccio A, et al. Beta-arrestin links endothelin $A$ receptor to beta-catenin signaling to induce ovarian cancer cell invasion and metastasis. Proc Natl Acad Sci U S A 2009; 106: 2806-11.

173 Zhang Y, Qian Y, Lu W, Chen X. The G protein-coupled receptor 87 is 
necessary for p53-dependent cell survival in response to genotoxic stress. Cancer Res 2009; 69: 6049-56.

174 Zhang Y, Scoumanne A, Chen X. G protein-coupled receptor 87: a promising opportunity for cancer drug discovery. Mol Cell Pharmacol 2010; 2: 111-6.

175 Jin Z, Luo R, Piao X. GPR56 and its related diseases. Prog Mol Biol TransI Sci 2009; 89: 1-13.

176 Tanese K, Fukuma M, Yamada T, Mori T, Yoshikawa T, Watanabe W, et al. G-protein-coupled receptor GPR49 is up-regulated in basal cell carcinoma and promotes cell proliferation and tumor formation. Am J Pathol 2008; 173: 835-43.

177 Qin Y, Verdegaal EM, Siderius M, Bebelman JP, Smit MJ, Leurs R, et al. Quantitative expression profiling of G-protein-coupled receptors (GPCRs) in metastatic melanoma: the constitutively active orphan GPCR GPR18 as novel drug target. Pigment Cell Melanoma Res 2011; 24: 207-18.
178 Gugger M, White R, Song S, Waser B, Cescato R, Rivière P, et al. GPR87 is an overexpressed G-protein coupled receptor in squamous cell carcinoma of the lung. Dis Markers 2008; 24: 41-50.

179 Glatt S, Halbauer D, Heindl S, Wernitznig A, Kozina D, Su KC, et al. hGPR87 contributes to viability of human tumor cells. Int J Cancer 2008; 122: 2008-16.

180 Tabata K, Baba K, Shiraishi A, Ito M, Fujita N. The orphan GPCR GPR87 was deorphanized and shown to be a lysophosphatidic acid receptor. Biochem Biophys Res Commun 2007; 363: 861-6.

181 Xu L, Begum S, Barry M, Crowley D, Yang L, Bronson RT, et al. GPR56 plays varying roles in endogenous cancer progression. Clin Exp Metastasis 2010; 27: 241-9.

182 Yang L, Chen G, Mohanty S, Scott G, Fazal F, Rahman A, et al. GPR56 Regulates VEGF production and angiogenesis during melanoma progression. Cancer Res 2011; 71: 5558-68. 